\title{
Several Roads Lead to International Norms, but Few Via International Socialization: A Case Study of the European Commission
}

\author{
Liesbet Hooghe
}

\begin{abstract}
Can an international organization socialize those who work within it? The European Commission of the European Union is a crucial case because it is an autonomous international organization with a vocation to defend supranational norms. If this body cannot socialize its members, which international organization can? I develop theoretical expectations about how time, organizational structure, alternative processes of preference formation, and national socialization affect international socialization. To test these expectations for the European Commission, I use two surveys of top permanent Commission officials, conducted in 1996 and 2002. The analysis shows that support for supranational norms is relatively high, but that this is more because of national socialization than socialization in the Commission. National norms, originating in prior experiences in national ministries, loyalty to national political parties, or experience with one's country's organization of authority, decisively shape top officials' views on supranational norms. There are, then, several roads to international norms.
\end{abstract}

To what extent can an international organization socialize those who work within it? In order for international institutions in Europe to socialize states and state agents into international norms, they must themselves emanate these norms. But can one simply presume that the people who work within international organizations share international norms, and if so, what are the causal mechanisms?

The Commission of the European Union (hereafter the European Commission) is a crucial case for examining socialization within an international organization.

For comments and advice, I am grateful to Jeffrey Checkel, Gary Marks, Donald Searing, and the editors and two anonymous reviewers for International Organization. An earlier draft was presented at the Center for European Studies of the University of North Carolina at Chapel Hill. This project received funding from the Center for European Studies, University of North Carolina at Chapel Hill, and from two grants by the Canadian Social Sciences and Humanities Research Council (1996-99, 1999-2002). Gina Cosentino, Erica Edwards, Michael Harvey, and Moira Nelson provided research assistance. 
Crucial cases "offer valuable tests because they are strongly expected to confirm or disconfirm prior hypotheses." ${ }^{1}$ Compared with other international organizations in Europe, such as the North Atlantic Treaty Organization (NATO) or the Council of Europe, the European Commission is extraordinarily autonomous and powerful, and this, socialization theory predicts, should make it the most likely site for socialization. The European Commission is the steering body of the world's most encompassing supranational regime. It has a vocation to identify and defend the European interest over and above — and if need be, against—particular national interests. It is the agenda setter in the European Union (EU). It also has the authority to select and groom its employees with minimal national interference. So there are strong reasons to expect international socialization to be effective in the European Commission. If this powerful body cannot shape its employees' preferences, which international organization can?

How can one make sense of top Commission officials' support for, or opposition to, the European Commission's core norms? Support in itself does not, of course, mean that officials have been socialized in the Commission. What are the scope conditions for international socialization? When does international socialization work, and when does it not? When do alternative processes of preference formation predominate? Can international officials learn international norms outside the international organization?

In this article, I set out a theory of preference formation in international organizations. I frame expectations concerning when international socialization may work, what shape it may take, and when it may be trumped by other processes or contexts. In the language of this special issue, I am concerned with specifying the scope conditions of international socialization. I build primarily on work in comparative and U.S. politics and political psychology, as well as recent work on socialization in international organizations, to develop a theory applicable in international contexts. The first section describes the European Commission and the norms it embodies. I then lay out hypotheses about when, how, where, and to what extent international socialization works. Finally, I evaluate the validity of these hypotheses against evidence from two surveys of senior Commission officials.

My conclusion is that, while support for international norms is high, this is not primarily because of socialization in the European Commission. Top officials sustain Commission norms when national experiences motivate them to do so-when national political socialization predisposes them to embrace supranationalism, or when supranationalism appears to benefit their country. Like Beyers' national bureaucrats in EU Council working groups, ${ }^{2}$ these quintessentially European bureaucrats take their cues primarily from their national environment. Several roads lead to Commission norms, but few run through international socialization.

2. Beyers, this volume. 


\section{The Engine of Europe}

The role of the European Commission is described precisely in the Treaty of the European Union and is reinforced by the Commission's house rules. The Commission has a constitutional obligation to set the legislative agenda in the European Union (EU). ${ }^{3}$ Unique among international institutions and unparalleled among executives in national democracies, the Commission has exclusive formal competence to initiate and draft EU legislation. ${ }^{4}$ It decides when regulation is necessary and how it should be devised. The Council of Ministers, which represents national governments, and the European Parliament, which is directly elected, may request the Commission to draft an initiative, but the Commission can, and sometimes does, refuse. The Treaty also instructs the Commission to serve the European interest. ${ }^{5}$ It also requires the Commission to be independent from any national government. ${ }^{6}$ These Treaty rules apply to the two levels of the European Commission: the political College, composed of the twenty-five commissioners appointed jointly for five years by member states and the European Parliament to give the Commission political guidance; and the Commission bureaucracy, consisting of approximately 24,000 permanent career civil servants selected through central European exams to take care of daily business.

It is with the career civil servants, and more precisely the most senior officials among them, that I am concerned. They are the men and women who soldier on as political Colleges—-led by Delors, Santer, Prodi, or Barroso-come and go. In addition to being bound by the Treaty, they are expected to adhere to the European Commission's internal staff regulations, which instruct that "an official shall carry out his duties and conduct himself solely with the interests of the Communities in mind; he shall neither seek nor take instructions from any government, authority, organisation or person outside his institution.... He shall carry out the duties assigned to him objectively, impartially and in keeping with his duty of loyalty to the Communities." 7

Constitutional rules and house rules create clear expectations-norms-that are expressly designed to guide Commission officials, whether as political appointees or as permanent career officials. They prescribe the Commission and its employees to (1) put the Union interest first (supranationalism), ${ }^{8}$ (2) construe what this

3. Article 211, Treaty of the European Union.

4. This monopoly has grown with the steady expansion of the Treaty's so-called pillar I from primarily internal market issues to political regulation, and the transfer of some pillar II and III issues, including aspects of asylum, immigration, and foreign policy, to pillar I. At the same time, the Commission's monopoly has been eroded by informal rules that give the European Parliament and the European Council certain rights to table initiatives.

5. Article 213.2, Treaty of the European Union.

6. Ibid.

7. Article 11, Staff regulations of Officials of the European Communities (May, 2004). Available from http://europe.eu.int/comm/dgs/personnel_administration, accessed on 23 August 2005.

8. As Haas points out, supranationality is an elusive concept. He defines supranationality as a hybrid between federalism and intergovernmentalism, whereby more power is given to the central agency 
means proactively (agenda setting), and (3) promote the Union interest independently from national pressures (impartiality and autonomy). ${ }^{9}$

These norms have deep roots. The Commission's founding father, Jean Monnet, saw the Commission as a small, organizationally flexible and adaptive, multinational nucleus of individuals at the European level, akin to the Planning Commission (Commissariat de plan) he had set up after World War II in France to devise the first five-year national economic plan. Liberated from national interests, its role was to develop ideas freely, to stimulate and persuade. The Commission's autonomy, pro-European bias, and exclusive power of initiative were crucial to this conception, and Monnet persuaded national leaders to anchor these principles in the Treaty. The notion that the European Commission is, and should be, the engine of Europe was born. ${ }^{10}$ This notion is a direct challenge to Westphalian state-centric norms in international relations. ${ }^{11}$ No other national or international organization, with the exception of the European Court of Justice, represents so patently the view that supranational interest is irreducible to national interests.

How widespread is support for these pro-European norms in the Commission itself? Do the people who work in the Commission support supranationalism, Commission agenda setting, and autonomy? Does this support arise because the Commission socializes those who work in it?

\section{Shaping Preferences in International Organizations}

Most research on international socialization examines states or state governments rather than individuals. ${ }^{12}$ In this analysis, I focus on individuals within an international organization. ${ }^{13}$

than is customary for conventional international organizations, but less than to a federal government. See Haas 1958, 34; see also Lindberg and Scheingold 1970, 14-21. The defining feature of supranationalism is that decisions are binding on member states. Supranationalism approaches federalism when decisions are made by independent European organizations, such as the European Court, European Parliament, or the European Commission.

9. The draft constitutional treaty of the European Union, signed on 29 October 2004 by the members of the European Council in Rome, restates these norms: (1) Supranationalism: Article 25.1: "The European Commission shall promote the general European interest and take appropriate initiatives to that end." (2) Agenda setting: Article 25.2: "Except where the Constitution provides otherwise, Union legislative acts can be adopted only on the basis of a Commission proposal." (3) Impartiality and autonomy: Article 25.4: "In carrying out its responsibilities, the Commission shall be completely independent. In the discharge of their duties, the European Commissioners and the Commissioners shall neither seek nor take instructions from any government or other body." The treaty is available at $\langle$ http:// europa.eu.int/futurum/constitution/ $\rangle$. Accessed 22 June 2005.

10. See Duchêne 1994; and Pollack 2003.

11. Caporaso 2000.

12. See Finnemore 1996; Hemmer and Katzenstein 2002; Linden 2002; and Risse, Ropp, and Sikkink 1999.

13. See Checkel 2003; Checkel, this volume; and Johnston 2001. 
Socialization refers to the process of inducting individuals into the norms and rules of a given community. ${ }^{14}$ The mechanisms by which this occurs may range from the self-conscious (for example, normative suasion) to the subconscious (for example, social mimicking or role playing), and from the instrumental (for example, shaming) to the noninstrumental (for example, communication). ${ }^{15}$

Socialization demands that individuals change their preferences in accordance with organizational norms. This poses a challenge for analysis because preferences cannot be observed from behavior. Preferences need to be researched directly, for example in structured interviews, to yield information that is independent from behavior. This research strategy is time-consuming, and even then, uncertainty lingers about the veracity of stated preferences. Respondents may lie, or they may not be able to express their true preferences. ${ }^{16}$ That is perhaps why social scientists treat preferences as exogenous. ${ }^{17}$

International socialization is present to the degree that individuals in an international organization support its mission as a result of experiences in the organization. One must diagnose a change in a person's mental state to show that norms have been internalized-Type II socialization, in Checkel's terms. ${ }^{18}$ What questions should one ask to uncover the scope conditions of international socialization?

- How do organizational experiences shape preferences over time? Is induction into organizational norms easier and faster for newcomers than for longtime members? Are younger recruits more likely to be socialized than older ones? How, in other words, does the rate of socialization vary over time?

- How does organizational fragmentation affect socialization? Socialization theory predicts that cohesive organizations are better at socializing agents than fragmented organizations.

- How does international socialization interact with national socialization? Individuals in international organizations usually come from diverse national backgrounds. When do national backgrounds reinforce, and when do they weaken, international socialization?

14. See Checkel, this volume; Conover 1991; and Hooghe 2002.

15. See Beck and Jennings 1991; Johnston 2001; Risse 2000; and Sears and Valentino 1997.

16. Deception and attitude softness can be problematic among ordinary citizens, as public opinion research has demonstrated. Zaller 1992. Attitude softness, however, is rarely an issue for elites whose views tend to be more crystallized on political objects. Jennings 1992. There is no fire-proof method for distinguishing true from deceptive preferences. I cannot discount the possibility that some respondents concealed their true preferences, though the circumstances of the interview (anonymity, voluntary participation, nonsensitive character of the questions), and the senior status of the respondents (considerable discretion, weak peer control) are reassuring.

17. In international relations, rationalists tend to take preferences as exogenous, while constructivists endogenize them. However, as Fearon and Wendt remind us, it is unwise to exaggerate the difference. Whether one endogenizes preferences is an analytical choice dictated by one's research question. See Fearon and Wendt 2003, 64. Preferences are the first step, and behavior the second step, in the two-step dance that is international cooperation. Legro 1996.

18. Checkel, this volume. 
- Can one splice the effects of socialization from alternative processes that induce support for organizational norms? To accurately assess whether support is due to socialization, one must control for self-selection, selective recruitment, and utility maximization.

- Does the effectiveness of socialization vary across beliefs? An organization's mission usually consists of multiple norms. Are some norms more open to socialization than others?

\section{How Do Organizational Experiences Shape Preferences over Time?}

Inculcating values is a gradual process: the longer one's involvement in an organization, the more one's beliefs can be expected to approximate that organization's norms. ${ }^{19}$ While socialization usually requires long-term exposure, some individuals need less time than others. Thus the rate at which individuals internalize individual norms varies.

Effect of novelty. Initial experiences are more influential than subsequent ones. People in a new situation (that is, newcomers) are likely to be disoriented and eager to conform. They are more susceptible to efforts of persuasion, and more disposed to copy what others do. ${ }^{20}$ As time goes by, views crystallize, that is, they become more consistent and stable. ${ }^{21}$ The marginal effect of time spent in an organization is illustrated in Figure 1, where the slope of the line $A A^{\prime}$ flattens as it approaches $t_{1}$.

Primacy. Socialization varies inversely with a person's age and experience. This is the primacy effect. Psychologists theorize that new experiences stick best when a person has few relevant prior experiences. ${ }^{22}$ There is debate about the optimal age for socialization and the extent to which older people become impervious to socialization. But even those who argue that core predispositions continue to crystallize well past adolescence accept that change takes place ever more slowly with age. ${ }^{23}$ One should therefore find that young recruits and people with minimal relevant prior experience—blank slates, or "baby generals" as Gheciu calls themare more susceptible to socialization than seasoned members. ${ }^{24}$ Young recruits and

19. Searing 1986.

20. See Johnston 2001; also Checkel 2003.

21. Sears and Funk 1999.

22. See Sears and Levy 2003; and Searing, Wright, and Rabinowitz 1976.

23. Sears and Funk 1999.

24. Gheciu, this volume. Novice and primacy effects are sometimes conflated, but they are analytically different. While the primacy effect is a function of age, the novice effect is a function of time spent in an organization. 


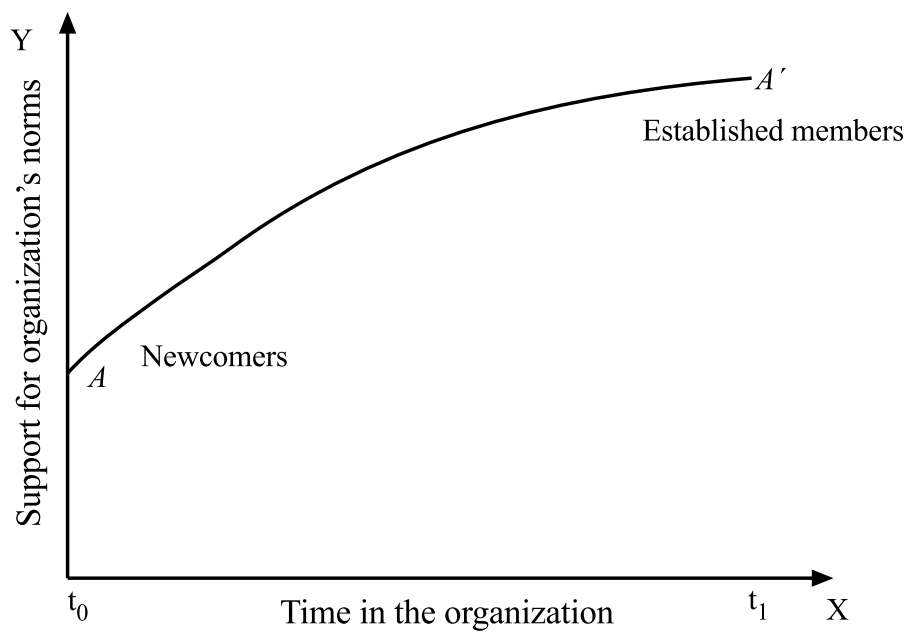

FIGURE 1. Mapping socialization

"blank slates" are represented in Figure 2 by the steep curve $A A^{\text {", while older }}$ recruits/experienced individuals are represented by the flatter curve $A A^{\prime \prime \prime}$.

These considerations temper one's expectations about the strength of socialization in international organizations. Few officials join international organizations

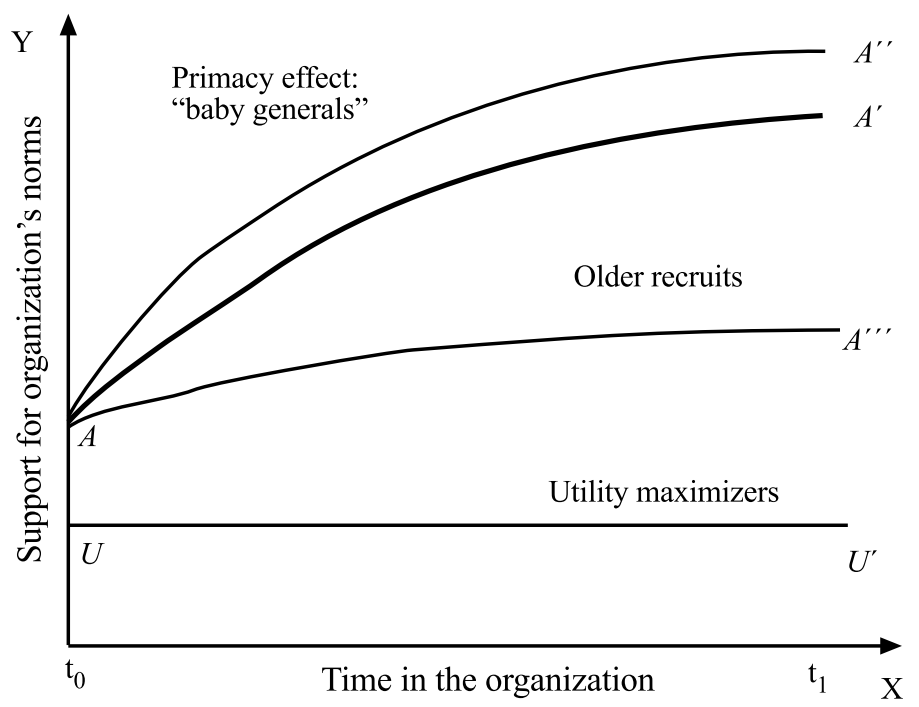

FIGURE 2. Socialization, utility, self-selection 
as young adults, top functions are often filled through lateral appointments of national diplomats or experts, and personnel turnover tends to be high. To the extent that recruits are older, experienced, or mobile, I hypothesize that the socialization curve will be flattened or truncated.

\section{How Does Organizational Fragmentation Affect Socialization?}

Organizations are rarely unitary. Compartmentalization multiplies opportunities for socialization, but it also produces diversity within an organization. Compartmentalization intensifies ties within organizational subunits while loosening those among them. Because members' experiences are usually more intense in organizational subunits, socialization is likely to be more effective there.

However, different subunits within an organization may socialize different norms, some of which may reinforce the international organization's mission, and others not. The socialization curve will be steeper when socialization in the unit reinforces the norms of the organization as a whole, and flatter when it does not.

Fragmentation is a trademark of many organizations, both international and national, especially when political leadership is weak or divided. In his seminal article on the Cuban Missile Crisis, Allison emphasizes how weak presidential leadership fostered bureaucratic fragmentation. When a bureaucracy is divided, he argues, bureaucrats are inclined to identify with their department's interest over and above that of the administration as a whole. ${ }^{25}$

\section{How Does International Socialization Interact with National Socialization?}

Most individuals are members of several organizations and are therefore exposed to competing norms, but the extent to which exposure leads to socialization depends on the boundedness of the organization. An organization is bounded to the extent that it controls its members, ${ }^{26}$ and in the last analysis, its members' life chances. Boundedness requires authority-over the mission of the organization, how it is to be pursued, and who should pursue it.

The relative boundedness of international organizations is usually constrained by national institutions. National institutions tend to have deeper historical roots, a more coherent mission, more extensive resources, and more cohesive membership than international organizations. The institutions of one's country of birth also tend to be most influential in pre-adulthood. ${ }^{27}$ Children know whether they are American, German, or French by the age of six or seven ${ }^{28}$ they acquire basic

25. Allison 1971.

26. Nordlinger 1981.

27. See Jennings and Stoker 2001; and Sears and Levy 2003.

28. Druckman 1994. 
beliefs about democracy, freedom, community, race, and rudimentary political allegiance and partisanship during adolescence. These political beliefs are cued by schools, parents, churches, media, associations, and peer groups in a particular national environment. Even in the age of globalization, nearly all individuals in Western societies grow up in one or, at most, two national states. So an international official's nationality comes with distinctive cultural baggage.

One should not assume that national institutions always dilute international norms. National institutions may actually deepen multilateral or supranational values. National and international socialization may produce the same outcome, and only an analysis sensitive to alternative contexts can disentangle these.

How might national context predispose individuals in one direction or another with respect to international norms? Countries vary widely in the degree to which they centralize or decentralize authority. Notwithstanding the United States and Switzerland, citizens of federal societies may have fewer inhibitions concerning supranationalism and multilevel governance.

Political parties constitute a second context for political socialization, and this is especially so with respect to the EU. European integration has become an issue that divides political parties and electorates. ${ }^{29}$ To the extent that international officials identify with a political party ideology, one would expect this to influence their views on international norms. Finally, I expect an individual's prior work experiences to matter. I anticipate that those whose career has led them abroad are more sympathetic to international norms. In contrast, individuals who have worked exclusively in their national civil service have been socialized to place the highest value on public service to their nation.

\section{Can One Distinguish Socialization from Self-Selection and Selective Recruitment?}

Socialization is only one of several processes that connect individuals to groups. Even if those who work in an organization support its norms, this may not be because of socialization. The alternatives are threefold. Members may share an organization's norms because those who choose to join the organization are already supportive (self-selection), because the organization screens recruits for their views (selective recruitment), or because self-interest induces employees to share the organization's norms (utility maximization).

Self-selection and selective recruitment precede socialization; they do not say anything about whether people are socialized once they join the organization. Hence, they do not affect the shape of the socialization curve, but they do affect the point 
of departure-in Figure 2, they shift the intercept of the socialization curve north along the y axis. ${ }^{30}$

\section{Can One Distinguish Socialization from Utility Maximization?}

Socialization theory states that individuals acquire preferences by internalizing norms embodied in the groups or institutions in which they live or work, or which are otherwise important to them. This view emphasizes affective group ties (identities) and long-standing personal dispositions. What motivates individuals is, in March and Olsen's words, "a logic of appropriateness." ${ }^{31}$ Utility theory, in contrast, maintains that preferences reflect self-interest, usually conceived in materialistic terms. Individuals have particular preferences because this is rational in light of costs and benefits. March and Olsen describe this as a "logic of consequentiality." 32

In many activities, individuals are motivated by some combination of identity and utility. ${ }^{33}$ But the extent to which each is present varies from issue to issue, and from context to context. The question is not simply whether socialization or utility maximization determines the preferences of members of international organizations, but under what conditions members tend to be more influenced by one or the other.

Splicing socialization from utility maximization demands careful surgery. Socialization, in contrast to utility maximization, is all about the temporal effects of group influence. The socialization curves in Figure 2 are time-sensitive in that they tap cumulative experience in an organization. Utility maximization is timeinsensitive: what matters are the incentives and disincentives that confront a person at a given moment ( $U U^{\prime}$ in Figure 2). ${ }^{34}$

Socialization theory hypothesizes that individuals have a psychological need to minimize inconsistent beliefs. Cognitive dissonance reduction, the psychological mechanism whereby individuals seek to reduce dissonance among various beliefs,

30. The distinction between self-selection and selective recruitment, on the one hand, and socialization, on the other, is hard to pin down empirically. What would be useful is data that allow $a$ ) comparison of the preferences of self-selected individuals with those of potential candidates who chose not to apply, and $b$ ) comparison of the preferences of selected applicants with those of rejected applicants.

31. March and Olsen 1989, 160.

32. Ibid.

33. See Chong 2000; Hooghe 2002; and Searing 1994.

34. Over the long haul, it is often a combination of utility and socialization that brings an individual to support organizational norms. Initially, when a person joins an organization, incentives, persuasion, and mimicking may all nudge them toward particular preferences, so that it is impossible to distinguish socialization from utility. In the long run, individuals may internalize norms. The litmus test is whether preferences change in tandem with changing material incentives. If they do, utility maximization guides preference formation; if they do not, it is socialization. I thank Don Searing for raising the issue of changing processes of preference formation over time. See also Johnston, this volume. 
decreases information costs and thus preempts rational calculation. ${ }^{35}$ An individual is more capable of reducing dissonance when the norm concerns diffuse values, and when the material stakes are low. I take a look at these in turn.

Large and diffuse norms. Socialization is more likely for norms that concern large or diffuse values in life. ${ }^{36}$ Rational choice, on the other hand, "is more powerful when applied to medium-sized problems like the purchase of a car or of a house." But "large problems, in which the choice can be expected to have wideranging consequences ... tend to fall outside the scope of the theory. Preference rankings over big chunks of life tend to be incomplete, and subjective probabilities over events in the distant future tend to be unreliable." ${ }^{37}$

Material stakes. Utility maximization prevails when norms are perceived to have material consequences that can be estimated with some accuracy, are large enough to matter, and when a person's choice will probably affect the outcome. ${ }^{38}$ Materialist content, transparency, large stakes, and personal impact correspond to central assumptions of rational choice concerning self-interest, information, and motivation. Utility maximization, then, is most likely to trump socialization when an individual's career chances are at stake. ${ }^{39}$

International norms that affect career chances or material outcomes, such as norms concerning tasks, work practices, and constituency relations, are more open to utility maximization. International norms that concern diffuse values, such as norms on international cooperation, multilateralism, supranationalism and intergovernmentalism, are more readily socialized.

I have theorized how individual characteristics, organizational variables, and type of norm affect socialization. Table 1 summarizes these. I now examine whether and how the European Commission socializes those who work in it.

\section{Socialization in the European Commission}

I draw on two surveys of senior permanent civil servants in the European Commission: director-generals, deputy director-generals, directors, senior advisors, and heads of cabinet. The first survey consists of semi-structured personal interviews averaging eighty minutes in length, which I conducted between July 1995 and February 1997. The same individuals answered thirty-six questions concerning their attitudes on EU and Commission-related topics. From September 2001 through February 2002, I mailed to all senior Commission officials a structured questionnaire

35. See Chong 2000; and Simon 1985.

36. See Goren 2001; Huddy 2003; and Taber 2003.

37. Elster 1990, 40.

38. See Elster 1990; Sears and Funk 1991; and Young et al. 1991.

39. See Chong 2000; Crano 1997; Sears 1993; and Taber 2003, 447-48. 
TABLE 1. Scope and mechanisms of socialization
Independent variable
Hypothesis

\section{Individual characteristics}

\begin{tabular}{ll}
\hline TIME IN ORGANIZATION & $\begin{array}{c}\text { Socialization is most intense for newcomers and decreases } \\
\text { over time. }\end{array}$ \\
PRIMACY (age when joining) & Inexperienced recruits are more rapidly socialized. \\
SELF-SELECTION & $\begin{array}{c}\text { Self-selected recruits are more likely to support organizational } \\
\text { norms. }\end{array}$
\end{tabular}

Organizational variables

\begin{tabular}{|c|c|}
\hline ORGANIZATIONAL FRAGMENTATION & Fragmentation inhibits unitary socialization. \\
\hline INCENTIVES (sanctions and rewards) & $\begin{array}{l}\text { Incentives may induce support for organizational norms } \\
\text { through utility maximization. }\end{array}$ \\
\hline
\end{tabular}

Type of norm

\begin{tabular}{ll}
\hline SUBSTANTIVE SCOPE OF ISSUE & Large/diffuse issues facilitate socialization. \\
SIZE OF MATERIAL STAKES & Transparent/sizeable material stakes facilitate utility \\
& maximization. \\
STABILITY OF NORM & $\begin{array}{c}\text { Unstable norms discourage preference structuring: } \\
\text { socialization and utility maximization are weakened. }\end{array}$ \\
&
\end{tabular}

replicating most of the 1995-97 questions. I also conducted short personal interviews with fifteen respondents in February 2002. Here I analyze responses to the two sets of closed-ended mail questionnaires, illustrated with direct quotations from transcribed interviews. ${ }^{40}$ Of a population of 204 and 230 senior Commission offi-

40. The value of closed-ended mail questionnaires for elite research is debated. Politically sophisticated actors tend to dislike closed-ended questions because it forces them to condense complex beliefs into blunt agree/disagree statements, while an interview allows them to be more subtle. In his elite study, Putnam reprints a letter from a British parliamentarian who makes this point. See Putnam 1973, 19. Likewise, I received a questionnaire from one official on which he had scribbled dense critical comments next to virtually every question but refused to take position on a single item! In their study of foreign policy makers, Hollis and Smith argue for taking accounts by elite actors seriously: "Our actors interpret information, monitor their performance, reassess their goals. The leading idea is that of reasoned judgment, not of manipulation" (emphasis in the original). See Hollis and Smith 1986, 283, quoted in Searing 1991, fn.17. How can one make closed-ended questionnaires serve this purpose? A first step is to draw heavily on previous research. Where feasible, I replicated content and format from Searing's study of British parliamentarians and Putnam's study of political elites. See Searing 1994; and Putnam 1973, respectively. This has the added value of comparability. Furthermore, I systematically pretested the questionnaire. Finally, I triangulated statistical analysis of the closedended elite questionnaires with qualitative reading of in-depth interviews. Personal interviews with 137 senior Commission officials produced 180 hours of taped interviews, so respondents had plenty of 
cials at the respective time points, 105 responded in 1996 and 93 in $2002 .{ }^{41}$ When question wording is consistent across surveys, I pool data, and this brings the sample to 198 .

It is useful to establish a baseline for comparison. How do the views of top Commission officials on European integration compare with those of other actors? One knows an increasing amount about preferences by EU actors, including the Council of Ministers, ${ }^{42}$ permanent representations, ${ }^{43}$ European parliamentarians, ${ }^{44}$ Commission officials, national civil servants, ${ }^{45}$ national governments, ${ }^{46}$ national political parties, ${ }^{47}$ interest groups,${ }^{48}$ and public opinion. ${ }^{49}$ But surveys often ask different questions.

Fortunately, there are some common points for comparison. An oft-repeated Eurobarometer question asks citizens how they want to distribute authority between the EU and national governments on thirteen individual policies. The same question was included in the 1996 national elite survey on attitudes concerning European integration, the only systematic survey of national elites to date in the fifteen pre-enlargement EU member states. ${ }^{50} \mathrm{I}$ also used the question in my 2002 survey of top Commission officials. ${ }^{51}$

time to explicate their views (in French or English). Closed-ended questionnaires were handed out after the interview. The idea is to maximize the distinctive advantage of closed-ended questionnaires-an objective, quantifiable basis for systematic comparison-while minimizing their disadvantages.

41. The higher response rate for the first survey ( 51 percent against 40 percent) reflects the fact that the personal interview had allowed me to establish rapport with the respondent. When necessary, I followed up by phone, e-mail, or fax. In 2001-2002, the procedure was more distant. A research assistant mailed questionnaires (in French and English) to 230 officials, but struggled to meet our target response rate. I wound up traveling to Brussels to set up fifteen short appointments, in which I asked respondents to fill out the questionnaire in my presence. I took care not to influence the process to ensure comparability with the mailed-in responses. The flying visit provided me with an opportunity for brief personal interviews. Facts and figures on response rate, sample bias, and interview strategy for the first survey are available in Hooghe 2002, and from my Web site at /http://www.unc.edu/ $\sim$ hooghe $/\rangle$.

42. Beyers, this volume.

43. Lewis, this volume.

44. Thomassen, Noury, and Voeten 2004.

45. Egeberg 1999.

46. Hug and König 2002.

47. Marks, Hooghe, Nelson, and Edwards forthcoming.

48. Wessels 2004.

49. See Gabel and Anderson 2002; and Van der Eijk and Franklin 2004.

50. The public opinion data are from Eurobarometer 54.1 of fall 2000. Hartung 2001. The national elite data were collected in 1996 by EOS Gallup-Europe, which drew a representative sample from a database of 22,000 individuals from five elite sectors: elected politicians (national and European parliamentarians), senior national civil servants, business and trade union leaders, media leaders (including heads of broadcast and print media), and cultural elites (persons playing a leading role in the academic, cultural, or religious life). The survey was conducted by telephone $(N=3778)$. See Spence 1996.

51. Question 30 in Eurobarometer 54.1 reads: "For each of the following areas, do you think that decisions should be made by the [nationality] government, or made jointly within the European Union? 1 = nationality, 2 = jointly within the European Union, 3 = don't know." Hartung 2001. The question formulation for national elites and Commission officials differs somewhat from that for public opinion, in that it allows respondents to indicate support or opposition on a scale from 1 to 10 . For comparability, elite data must therefore be transformed into a dichotomous variable. See Hooghe 2003. 
TABLE 2. National and European identity among Commission officials and the public

National attachment

\begin{tabular}{lcccccc}
\hline & $\begin{array}{c}\text { Not at all } \\
\text { attached }\end{array}$ & $\begin{array}{c}\text { Not very } \\
\text { attached }\end{array}$ & $\begin{array}{c}\text { Fairly } \\
\text { attached }\end{array}$ & $\begin{array}{c}\text { Very } \\
\text { attached }\end{array}$ & $\begin{array}{c}\text { Don't } \\
\text { know }\end{array}$ & $\begin{array}{c}\text { Average on } \\
\text { 4-point scale }\end{array}$ \\
\hline Public & $1.4 \%$ & $8.0 \%$ & $38.1 \%$ & $51.7 \%$ & $0.7 \%$ & $3.4 *$ \\
Commission & $3.3 \%$ & $10.9 \%$ & $46.7 \%$ & $39.1 \%$ & $0 \%$ & $3.2 *$ \\
\hline
\end{tabular}

European attachment

\begin{tabular}{lcccccc}
\hline & $\begin{array}{c}\text { Not at all } \\
\text { attached }\end{array}$ & $\begin{array}{c}\text { Not very } \\
\text { attached }\end{array}$ & $\begin{array}{c}\text { Fairly } \\
\text { attached }\end{array}$ & $\begin{array}{c}\text { Very } \\
\text { attached }\end{array}$ & $\begin{array}{c}\text { Don't } \\
\text { know }\end{array}$ & $\begin{array}{c}\text { Average on } \\
\text { 4-point scale }\end{array}$ \\
\hline Public & $9.4 \%$ & $27.4 \%$ & $41.7 \%$ & $18.1 \%$ & $3.4 \%$ & $2.7 * *$ \\
Commission & $2.2 \%$ & $19.4 \%$ & $50.5 \%$ & $24.7 \%$ & $1.1 \%$ & $3.0^{* *}$ \\
\hline
\end{tabular}

European or national identity

\begin{tabular}{lcccccc}
\hline & $\begin{array}{c}\text { European } \\
\text { only }\end{array}$ & $\begin{array}{c}\text { National } \\
\text { and } \\
\text { national }\end{array}$ & $\begin{array}{c}\text { and } \\
\text { European }\end{array}$ & $\begin{array}{c}\text { National } \\
\text { only }\end{array}$ & $\begin{array}{c}\text { Don't } \\
\text { know/ } \\
\text { refuse }\end{array}$ & $\begin{array}{c}\text { Average on } \\
\text { 4-point scale }\end{array}$ \\
\hline Public & $3.4 \%$ & $5.8 \%$ & $45.3 \%$ & $42.4 \%$ & $3.1 \%$ & $3.3^{* *}$ \\
Commission & $2.2 \%$ & $43.0 \%$ & $38.7 \%$ & $0 \%$ & $16.1 \%$ & $2.4 * *$ \\
\hline
\end{tabular}

Note: Scales range from 1 (not at all attached; European only) to 4 (very attached; national only). The last column reports difference of means tests, whereby $* * p<.001 ; * p<.05$. The public opinion data are from Hartung 2001, $N=16,061$; data for Commission officials are from the author's survey in 2002, $N=93$.

Top Commission officials appear significantly more pro-European than either national elites or public opinion across the thirteen policies for which we have comparable data. ${ }^{52}$ Average support among Commission officials is 65 percent, against 56 percent for national elites, and 53 percent for the public.

This pro-European bias is reflected in perceptions of identity (see Table 2). When Eurobarometer asks citizens to signal how much they are attached to their country and how much to Europe, European attachment is no match for national attachment, as the averages in the last column show. National attachment has a significantly smaller lead among top Commission officials. Top Commission officials are also much less likely to characterize their identity as exclusively national than

52. Hooghe 2003. The thirteen policies are currency, humanitarian aid/Third World, foreign policy, immigration and asylum, environment, agriculture, defense, research and development, regional policy, employment, social inclusion, health policy, and education. Of the twenty-six one-way analysisof-variance means tests for group differences - thirteen are between Commission officials and public opinion, and thirteen are between Commission officials and national elites - twenty are significant at the .001 level, one at the .01 level, one at the .05 level, and only four are insignificant $(p>.05)$. The results are robust across the Bonferroni and Tukey methods. 
are ordinary citizens. Forty-three percent of citizens describe themselves as "national only," but not a single official in the sample is so inclined. ${ }^{53}$

To summarize, Commission officials are more likely to identify with Europe and are more in favor of shifting policy to the European level than national elites or citizens. There is, then, considerable support among top Commission officials for the Commission norm of supranationalism. Is this because the Commission has socialized its officials, or for other reasons?

\section{What Explains Commission Officials' Views on Supranationalism?}

Table 3 presents a multivariate ordinary least squares (OLS) regression explaining top officials' preferences on supranationalism, which is measured by two items tapping whether member states or supranational institutions should be central pillars of EU governance (see Appendix 1 for wording and statistics).

To estimate accurately the effect of international and Commission socialization, one must control for socialization outside the Commission and for utility. Table 3 reports that Commission socialization (measured as length of service in the Commission) and international socialization (measured as having studied abroad) are not significant. ${ }^{54}$ In contrast, variables that capture socialization outside the Commission (that is, experience in a federal vs. unitary political system, ideology, and prior experience in a national administration) are highly significant. Utility maximization (that is, national economic benefit) also has a significant effect. Officials from countries that are net beneficiaries from EU policies are more likely to be supranationalist.

Figure 3 illustrates the relative effect of these variables. The solid boxes encompass the interquartile range and the whiskers indicate the 5th to the 95th percentiles, holding all other independent and control variables at their means. For example, an individual at the 5th percentile on FEDERALISM has a score of 3.8 on SUPRANATIONALISM on a 1-7 scale, and an individual at the 95th percentile scores 5.7. The variables toward the left of Figure 3 have the largest effect across their interquartile range. The three most powerful variables relate to socialization outside, rather than within, the Commission. International education and length of service in the Commission are considerably weaker, as is utility maximization. I now take a closer look.

53. The question is: "In the near future, do you see yourself as (1) [nationality] only, (2) [nationality] and European, (3) European and [nationality], or (4) European only?" Note that 16 percent of top officials (against 3.1 percent of the public) refused to choose one or the other option. Follow-up questions show that some officials object to having to rank European and national identity.

54. The argument for including international education is that it reinforces transnational norms, as students abroad are exposed to different ways of thinking and living. This happens during young adulthood when the primacy effect is powerful. Foreign students also experience firsthand that expatriates have limited citizenship rights compared to nationals at home, and I expect this to strengthen support for supranational institutions that could create overarching rights. 
TABLE 3. Explaining supranationalism

\begin{tabular}{lcc}
\hline & All officials & Primacy group \\
\hline Constant & $4.381(.655)^{* *}$ & $4.313(1.253)^{* * *}$ \\
International socialization & & \\
$\quad$ LENGTH OF SERVICE IN COMMISSION & $0.014(.014)$ & $0.077(.032)^{*}$ \\
$\quad$ INTERNATIONAL EDUCATION & $0.156(.121)$ & $0.262(.193)$ \\
Socialization outside Commission & & \\
$\quad$ STATE STRUCTURE (DISPERSED VS. UNITARY): & $0.187(.042)^{* *}$ & $0.077(.083)$ \\
$\quad$ FEDERALISM & $-0.012(.005)^{*}$ & $-0.013(.009)$ \\
$\quad$ SIZE OF COUNTRY & $-0.110(.075)^{\circ}$ & $-0.345(.139)^{*}$ \\
$\quad$ IDEOLOGY & $-0.031(.019)^{\circ}$ & $0.070(.103)$ \\
$\quad$ YEARS IN NATIONAL ADMINISTRATION & $0.033(.058)$ & \\
Utility factors & $0.180(.121)^{\circ}$ & $0.003(.098)$ \\
$\quad$ POWER-DG UTILITY & 0.226 & $0.300(.363)$ \\
$\quad$ NATIONAL ECONOMIC BENEFIT & 0.182 & 0.240 \\
$R^{2} \quad 198$ & 0.111 \\
Adjusted $R^{2}$ & & 78 \\
$N$ & &
\end{tabular}

Note: Ordinary least squares (OLS) are used in models for all officials and for the primacy group. The dependent variable (preferences on supranationalism) and the independent variables are detailed in Table A1 of Appendix 1. Coefficients are unstandardized. Standard errors are in parentheses. OLS regression analyses with pairwise deletion. Significance at $* * p<.01 ; * p<.05 ;{ }^{\circ} p<.15$;

\section{How Do Commission Experiences Shape Preferences Over Time?}

The effect of Commission socialization is modest: an additional year of service increases supranational support by 0.014 on a seven-point scale. At this rate, and controlling for the factors in Table 3, it would take seventy-one years to see someone who begins to work in the Commission as a neutral (four on our seven-point scale) change into a mild supranationalist at five.

But this conclusion does not hold for all Commission officials. The effect of Commission socialization is considerably stronger for the seventy-eight officials who joined the organization before their thirtieth birthday-the primacy group (see Table 3, second column). ${ }^{55}$ The relative weight of international and national socialization is reversed. The effect of length of service is outweighed only by party ideology, and it is considerably stronger than federalism, national career, and country size. Each additional year of Commission service increases support by 0.077 on a seven-point scale. So "baby generals" need some thirteen years to change from a neutral four on the supranationalism scale to a mild prosupranationalist position of five. Commission socialization is concentrated among this group.

55. Severe multicollinearity precludes testing the primacy effect in a single equation with overall Commission socialization (length of service). 


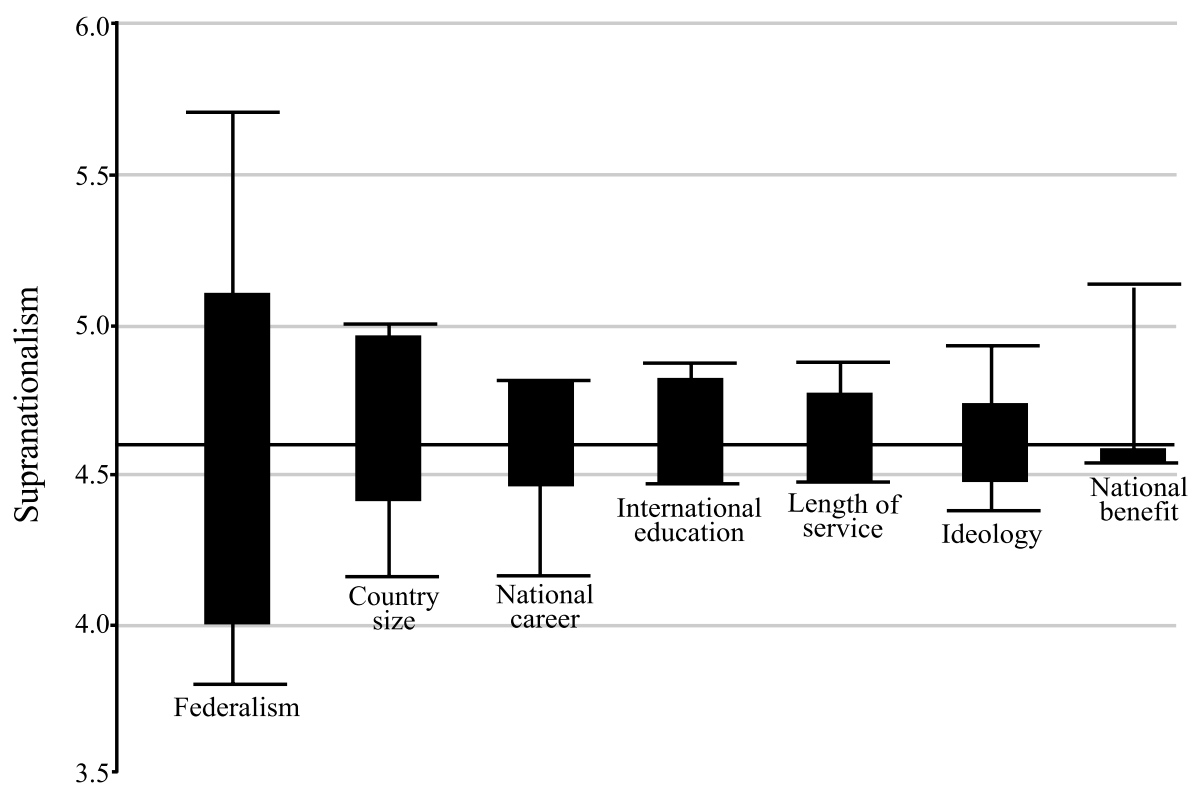

Interquartile range for independent variable in fully specified model where all other variables are held at their means.

T 5 percent -95 percent range for independent variable in fully specified model where all other variables are held at their means.

FIGURE 3. Effects of independent variables

There is no support for the hypothesis that newcomers are more susceptible to socialization, or that the rate of socialization decreases with years of exposure. ${ }^{56}$ The marginal effect of an additional year in the Commission is more or less linear with respect to time served.

Newcomers in the European Commission try hard to understand the rules and norms in their new organization. However, understanding rules is one thing, being persuaded by them is another. As one recently appointed Italian top official put it: "This is a huge organization, and when you arrive the first thing you do is to try to understand what is going on in the house. Of course, I do have, let's say, my own prejudices in this area and I did give some messages, but in the beginning most of the effort is in understanding." An Austrian top civil servant, six months on the job, echoed this. When asked whether she had the sense, in the first few weeks, that she would be able to pursue her goals, she replied: "My main interest was to fully

56. I tested this in several ways. I defined newcomers as those with up to two, up to three, up to five or up to seven years of service. Under no conditions is the difference between their rate of socialization and that of seasoned officials significant. I also tested several nonlinear permutations of length of service; none is superior to linearity. 
capture what was going on and how it functioned - taking stock of things and how things were done." The prevailing attitude among newcomers appears to be to wait and see, and not, as one might expect, mimicking behavioral norms of the group.

Socialization is not helped by the fact that Commission rules and norms are often difficult to grasp. Several Commission officials whom I interviewed vividly recalled their bewilderment in coming to grips with the complex interplay between multicultural attitudes and national particularities, the charged politicking in an apparent bureaucratic organization, the paper bureaucracy which all condone but few take seriously, and the paradox of widespread informal networking in a formalistic hierarchy. This complexity undercuts normative transparency and inhibits socialization. Learning to circumvent formal norms is essential to survival. An official who worked his way up in the Commission to the absolute top summarizes the duplicitous character of work norms:

The Commission only works when hierarchy is put aside. While we respect the hierarchy in formal terms, we know that, to get this job done, we need to ask the question: "Who do we need to do it?"... We are task-oriented, person oriented. That requires a great deal of flexibility and adaptability. It's not possible to operate, except through an at best token acceptance of procedures and hierarchies. The only way to make this thing work effectively within the deadlines set by politics is by relying on key people committed to the same goal. In a private organization, you have blanket indoctrination of everyone concerned into the goals of whatever you are producing, whether it is a production program or the launching of a new product or a new financial exercise, every single person goes through something akin to a propaganda exercise. This does not happen in the Commission. You have to form informal coalitions ... allies in the cause of a particular advancement of the policy from here to there."

\section{Does Organizational Fragmentation Affect Socialization?}

It is conventional wisdom that bureaucratic fragmentation in the Commission encourages local cultures, ${ }^{57}$ and one would expect this to influence Commission socialization. Coombes, an early student of the Commission, described the Commission as a collection of feudal fiefdoms. ${ }^{58}$ Cram conceives of the European Commission as a multi-organization, where subunits have their own goals and operational style. ${ }^{59}$ Since the late 1980 s, the Commission bureaucracy has also been scattered over some thirty-five buildings across Brussels, while in the old days many worked within walking distance of the Commission headquarters in the Berlaymont building on Schuman square. Spatial separation is said to have reinforced a culture of fiefdoms. 
If the Commission is as fragmented as many observers and some policymakers claim it is, directorates with extensive supranational competences and discretionary budgets should be more effective in instilling supranational norms. This is not the case. ${ }^{60}$

The explanation appears to be mobility. Mobility hinders identification with a particular unit. In the mid- to late 1990s, the average time a top official spent in a particular top position was less than five years. Consider these statistics: of the people I interviewed in 1996, more than half had left the European Commission by September 2001, and 25 percent had changed departments. With a turnover rate among top officials of 75 percent over five years, there is not much time to mold individual preferences according to particular departmental cultures. After the Santer Commission resigned in 1999 over allegations of fraud, mismanagement, and nepotism, the newly appointed commissioner for personnel, Neil Kinnock, required top officials to change posts every five to seven years. ${ }^{61}$ Contrary to common beliefs, only a small group of top officials is entrenched in a departmental world. Kinnock's mobility rules merely formalized common practice.

High rates of interdepartmental mobility should privilege overarching Commission norms. Interdepartmental coordination, which compels top officials to clear their departmental policies with other departments, should reinforce this. The apex of this elaborate coordination network consists of weekly meetings of directorgenerals, where interdepartmental Commission business is settled.

\section{Limits to the Commission's Boundedness: National Socialization}

Table 3 strongly supports the contention that national socialization may be more effective than international socialization in shaping international officials' preferences. National socialization appears double-edged, as noted by authors in this issue. On the one hand, national socialization depresses support for supranationalism among former national civil servants. On the other, national socialization engenders support for international norms. The best predictor of top officials' support for supranationalism is whether they come from a federal country. Core beliefs about national governance shape preferences on European governance. Federalism divides sovereignty, and this notion underpins multilevel governance. ${ }^{62}$ Thus, controlling for other factors, a Commission official who grew up in Belgium or

60. For the 1996 sample, I calculate for each official the number of years he spent in departments with extensive legal competences or a significant discretionary budget, and I call this variable POWERDG/SOCIALIZATION. I also calculate the alternative utility hypothesis, i.e., officials who happen to work in a supranational department have career reasons to favor supranationalism, which is labeled POWERDG UTILITY. As the OLS regression in Table A in Appendix 2 illustrates, neither hypothesis bites.

61. Kinnock made these measures public in a press statement on 29 September 1999 . Strictly speaking, the new rules make rotation mandatory only for director-generals, but in practice, directors have also been forced to rotate. Author's interview with a member of the Kinnock cabinet, February 2002.

62. See Hooghe and Marks 2003; Keohane 2002; and Risse 2001. 
Germany is more favorably disposed to supranationalism than one raised in Britain or France.

Contexts outside the Commission are powerful. The European Commission cannot afford to be a bounded institution. Shared authority is a vital feature of EU decision making. In few, if any, policy areas can one institution, national or European, take authoritative decisions unilaterally. ${ }^{63}$ The European system of multilevel governance plugs top Commission officials into diverse institutional contexts. It is necessary and natural for Commission officials to be attuned to national governments, political parties, public opinion, and other EU institutions, as well as to their international organization.

The pull of national contexts is consistent with the socialization literature. Unlike international organizations, national institutions-from families to schools to governments-draw full advantage from the primacy effect. European children grow up in national contexts, and such contexts leave imprints that are hard to dislodge later in life.

It is instructive to compare national civil servants with European Commission officials. National civil servants work for powerful national governments that represent imagined communities having concrete expression in national systems of welfare or education, as well as bloc votes in the EU Council of Ministers. The notion of national public interest has a tangible core. ${ }^{64}$ European public interest is shallower. While the EU has acquired some trappings of nationhood-an anthem, a flag, a public holiday, a European driver's license, a European passport, a European currency, membership of international organizations-these symbols register weakly in people's minds. Few outside the European institutions know that 9 May is Europe's "Independence Day." The Euro is the single exception in terms of capturing public attention, but its virtue is contested. ${ }^{65}$ National civil servants speak for deeply rooted national communities, while Commission officials speak for a potential community. ${ }^{66}$ The "gravitational pull" of the national often overwhelms that of Europe, even for those who work in the Commission. A long-serving top official describes this astutely:

There is a clear difference between national administrations and the Commission. National administrations have a broad consensus on objectives. All civil servants are interested in pulling the same cart, and they know in which direction and when to pull the cart. They may disagree about marginal adjustments or speed, but they basically all agree on where they want to go and what the national interest is. To use the word "national interest" gives immediately away why this cannot be the case inside the Commission. Even though we are supposed to work for the common interest of the Community, nobody

63. See Hooghe and Marks 2001; and Pollack 2000.

64. Page and Wright 1999.

65. For many Europeans, it is associated with economic hardship, as its popular German nickname, Euro-Teuro (expensive Euro) illustrates.

66. See Abélès and Bellier 1996; and Shore 2000. 
forgets his background, his nationality. Much of the conflict between national interests has been transferred to the Commission. Some [officials] are almost unashamed of it; they go straight for it and make it no secret. Others-and I think this is also a question of how long you have been in the Commissionwork much more for the common benefit. They tend to take a rationalreasoned balanced Community approach, whereas others choose a nationalinterest approach. So, national tensions are transferred to the Commission, and that makes it impossible to have everybody agree ex ante on common objectives. There are no common objectives. ... This is still a relatively young, expanding and maturing institution, which has not yet found its own identity.

\section{What Is the Role of Self-Selection and Selective Recruitment?}

Socialization is only one of several processes by which members of an organization may come to support organizational norms. In this section, I discuss how self-selection and selective recruitment shape supranational preferences. In the next section, I demonstrate that material incentives help account for the views of top Commission officials.

One knows that top Commission officials, including recent recruits, are more in favor of shifting powers to the EU than either national elites or public opinion. This may, in part, result from self-selection. As the so-called engine of European integration, it is likely that the Commission appeals to "believers."

Evidence from interviews suggests that self-selection plays a role, but the effect may be more limited than is often assumed. When top officials are asked why they joined the Commission, about one-quarter talk about European integration as an ideal, which guarantees, or partially guarantees, peace, democracy, order, or good governance. As an older Dutch official explains, "I am a child of the war. People of my generation would do anything to avoid a third world war. We did not have a sophisticated notion of an institutionalized Europe, but we were deeply European because we never wanted to repeat that experience." Officials from Spain, Portugal, and Greece often mention that European integration helped consolidate their young democracies.

However, most officials cite more pragmatic reasons for joining the Commission, including building a career (39 percent); national connections (21 percent, for example, their government asked them to apply); connections in the policy community (21 percent, for example, they were approached when serving as national experts in Council or Commission working groups); party-political connections ( 8 percent); or the desire for a policy challenge (11 percent). ${ }^{67}$ Overall, then, most officials enter the Commission for other than idealistic reasons. Selfselection motivates only a minority. 
There is also limited evidence of pro-European selective recruitment. Formal recruitment rules allow the Commission to select officials on the basis of their preferences if it so wishes. The most supranational Commission president over the past three decades, Delors, took these rules to heart: he searched for officials who would press forward his supranational agenda. According to Ross, "Delors, with Pascal's [Lamy, Delors' chef de cabinet] advice, had very carefully replaced a considerable number of high Commission officials, directors-general and division heads, in critical areas." ${ }^{68}$ But there is no firm statistical support for this in the data. Although Delors recruits tended to be more supranational than those recruited into top positions before or after Delors, the difference falls short of significance. There is no effect at all for the Santer or Prodi Commissions ${ }^{69}$ The Commission could, if it so chooses, influence its normative intake. But it rarely does so.

\section{Can One Distinguish Socialization from Utility Maximization?}

I have theorized that the effect of socialization depends on what is being socialized. The more a Commission norm invokes diffuse or large values, the greater the scope for socialization. Utility maximization, by contrast, should be stronger for norms that regulate tasks, work practices, and constituency relations-norms, in other words, with immediate career implications.

In the introduction, I identified three norms that characterize the Commission's mission: supranationalism; Commission agenda setting; and autonomy from national influence. How do the effects of socialization and utility vary across these?

Supranationalism is a prime example of a diffuse norm. It is nearly impossible for top officials to anticipate how a more supranational European Union may affect them professionally. Supranationalism has ambiguous career implications. On the one hand, more supranationalism means more policy tasks and resources. But on the other, it implies upgrading the College of Commissioners to the government of Europe, and this would imply downgrading permanent officials to mere civil servants. So one would expect socialization to be strong, and personal career utility to be weak, in shaping officials' norms regarding supranationalism.

Contrast this with the norm prescribing autonomy from national pressures. This is a norm with transparent implications for top officials' careers. Should the Commission's personnel system be strictly Weberian and reward merit over and above nationality, or should it reflect national quotas? National quotas punish qualified

68. Ross 1995, 67.

69. I seek to capture the effect of selective recruitment by respective Commission presidents by means of three dummies - one each for individuals appointed to top positions under Jacques Delors (1986-94), Jacques Santer (1995-98), and Romano Prodi (1999-2002). The OLS regression in Table A5 in Appendix 2 shows that none of these effects is significant. 
candidates having the "wrong" nationality. That is to say, officials from smaller countries are disadvantaged because small countries have relatively few top slots to fill, and so are officials who have not cultivated strong national connections that could catapult them into national slots. Contrast the fate of two respected directors, one Dane and one Greek, interviewed in 1996. The Dane's ambition to reach the summit—director-general—was dashed when a younger compatriot with better political connections was promoted to the top slot reserved for Denmark. The Greek director rated his chances for promotion as virtually nil because the two Greek top-rank posts had recently been taken up. Fast-forward to 2002, when the Danish official had taken early retirement, while his Greek colleague was just promoted. What had happened? The Commission resignation crisis in 1999 changed the prospects for the Greek director when one of the two top Greeks was sacked under a cloud of negligence and alleged fraud. So, unexpectedly, a window of opportunity opened briefly and then closed again. A merit-based promotion system, on the other hand, disadvantages candidates from recent member states, who usually have less experience with the Commission's way of working. One would therefore expect support for the norm of Commission autonomy to vary in tune with utility considerations, such as the strength of national or political connections, the size of a country's quota, or the timing of a country's membership, while socialization is expected to be weak.

Finally, one would expect support for the norm of Commission agenda setting to be influenced by both socialization and utility. This norm is diffuse in that it embodies Monnet's vision of the Commission as the engine of Europe; consequently, it should be amenable to socialization. But the norm also has calculable implications for officials' careers, in that it privileges a particular type of Commission activity (creating new policies) above another (administering existing policies); therefore, one would expect that utility calculations, informed by whether they are vested in one or the other kind of activity, to matter as well.

Tables $4 \mathrm{a}, 4 \mathrm{~b}$, and $4 \mathrm{c}$ allow one to evaluate the relative effects of socialization and utility on these norms. Table 4a presents OLS models explaining variation among Commission officials on the norm of supranationalism; Table $4 \mathrm{~b}$ provides the same for Commission agenda setting; and Table $4 \mathrm{c}$ presents models explaining variation on the norm of autonomy from national influence. Each table reports three explanatory models for two time points, 1996 and 2002..$^{70}$ The first two columns in each table represent socialization variables; the following two columns represent utility variables; the final two columns combine socialization and utility variables.

The coefficients of determination $\left(R^{2}\right)$ at the bottom of each table estimate the proportion of variance explained by each model. Socialization has the greatest causal weight for supranationalism (Table 4a); socialization is about evenly balanced with utility maximization for Commission agenda setting (Table $4 \mathrm{~b}$ ); and in

70. Appendix 3 hypothesizes causal effects and operationalizes variables. 
TABLE 4a. Explaining supranationalism: Socialization versus utility

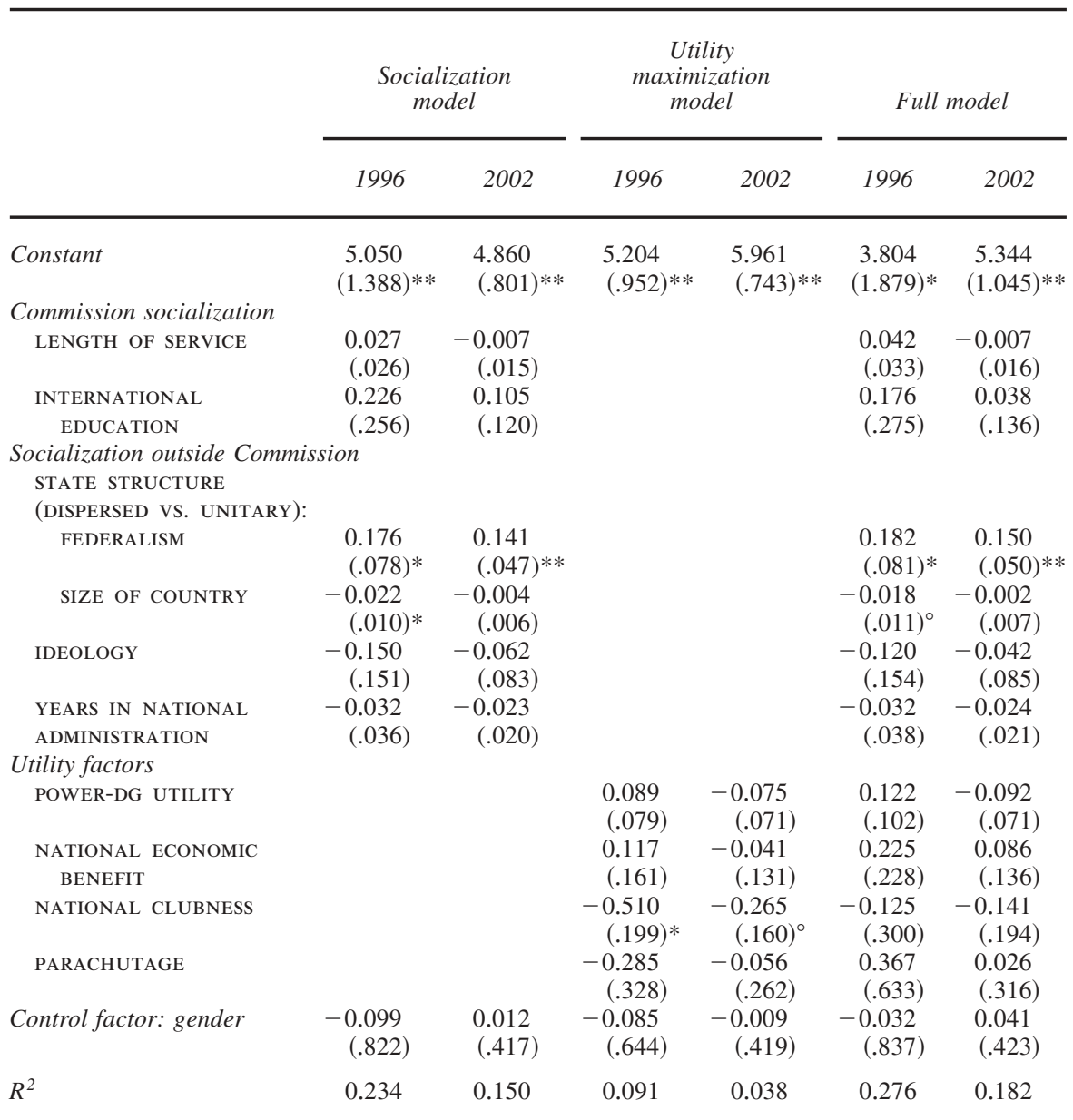

Note: Ordinary least squares (OLS) regression analyses with pairwise deletion. The $N$ is 105 for 1996 and 93 for 2002. Dependent and independent variables are detailed in Appendix 3. All models in this and the following tables control for gender. Significance at $* * p<.01 ; * p<.05 ;{ }^{\circ} p<.15$.

Table 4c, socialization is dwarfed by utility maximization for the norm of autonomy from national influences. These results are consistent across time points, with the exception of 2002 for the autonomy norm.

Furthermore, the results in Tables $4 \mathrm{a}, 4 \mathrm{~b}$, and $4 \mathrm{c}$ highlight a point made above: socialization requires stable norms; utility maximization requires transparent incentives. Commission norms became less stable and less transparent after the resignation of the Santer Commission in 1999, which happened in the face of allegations 
TABLE 4b. Explaining views on Commission agenda setting:

Socialization versus utility

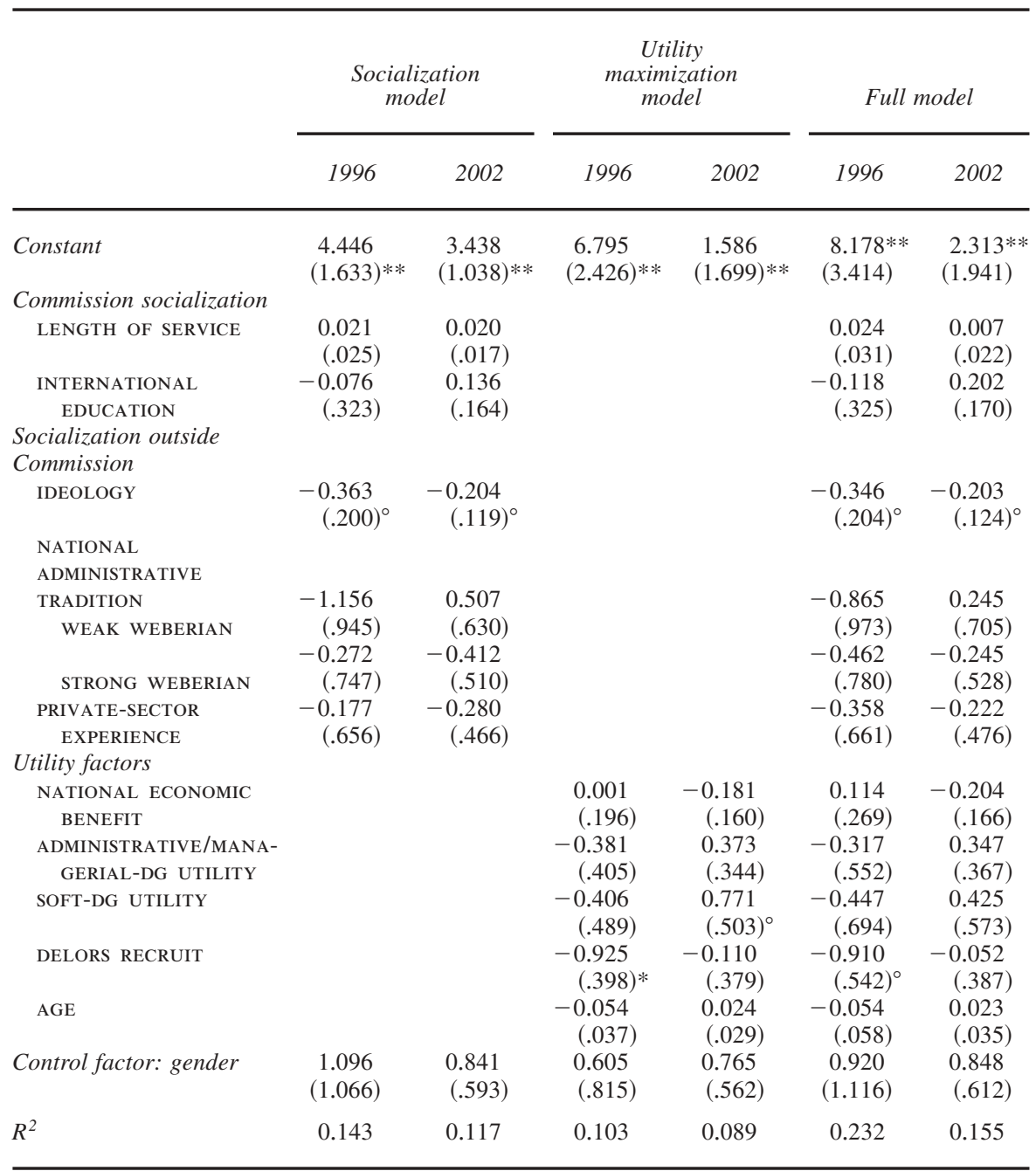

Note: Ordinary least squares (OLS) regression analyses with pairwise deletion. The $N$ is 105 for 1996 and 93 for 2002. Dependent and independent variables are detailed in Appendix 3. Significance at $* * p<.01 ; * p<.05$; ${ }^{\circ} p<.15$.

of fraud, mismanagement, and nepotism. The result is that top officials' views in 2002 are markedly less structured than in 1996. The 2002 data capture an organization in turmoil. The crisis shattered consensus in the Commission around the agenda-setting norm, which prescribes that the European Commission's primary 
TABLE 4c. Explaining views on Commission autonomy:

Socialization versus utility

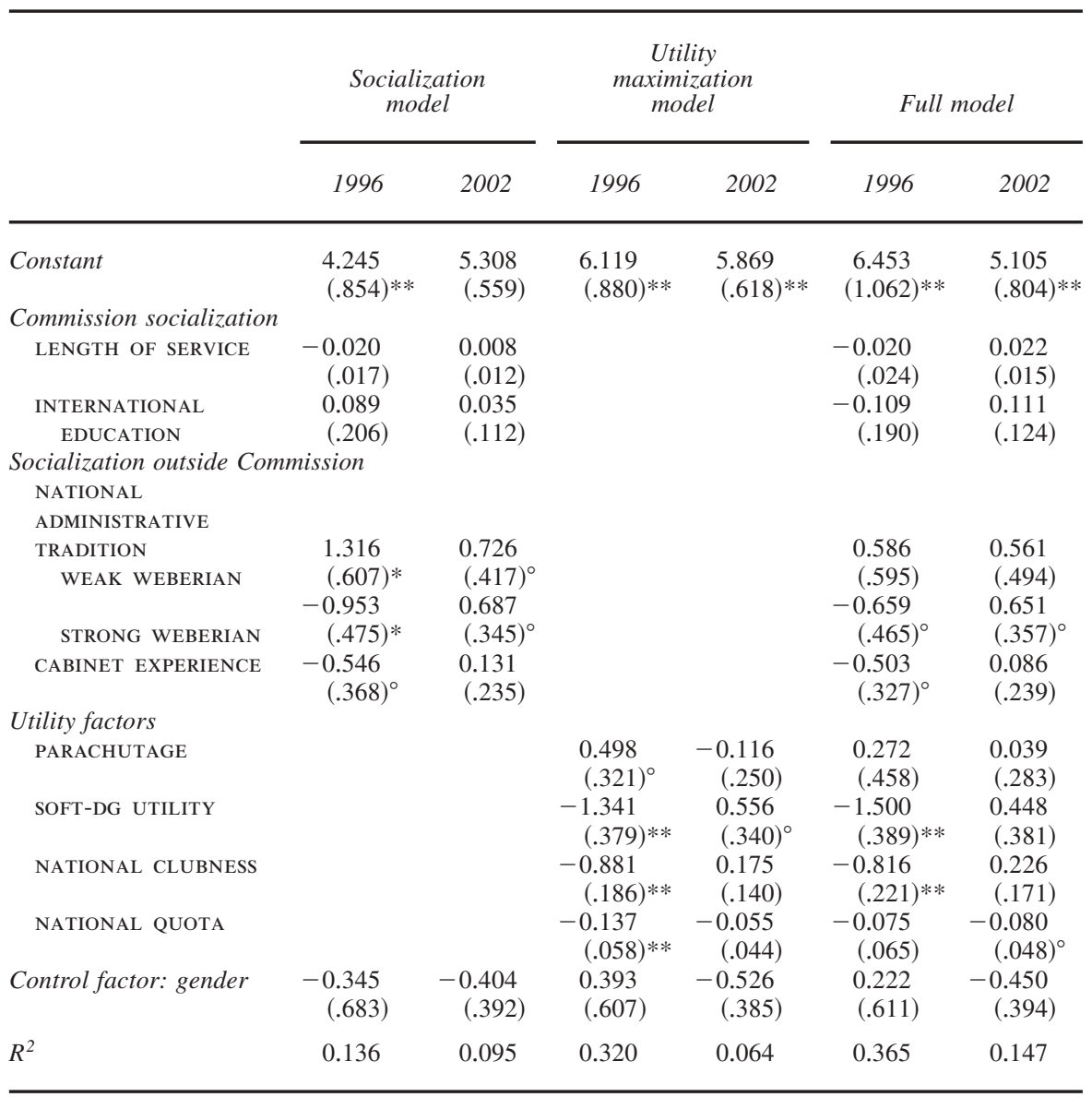

Note: Ordinary least squares (OLS) regression analyses with pairwise deletion. The $N$ is 105 for 1996 and 93 for 2002. Dependent and independent variables are detailed in Appendix 3. Significance at $* * p<.01 ; * p<.05$; ${ }^{\circ} p<.15$.

role is to initiate, not administer, EU policies (see Table 4b). In 1999, a new Commission team under Romano Prodi began rewriting internal work practices to encourage "sound management," and thus shifted the focus from policy creation to management. The crisis also forced the organization to face up to a duplicitous personnel policy whereby the norm of autonomy from national influences (see Table 4c) was contradicted by the practice of national quotas in top appoint- 
TABLE 5. Scope and mechanisms of socialization: Evidence

Socialization is most intense for newcomers and decreases over time. Inexperienced recruits are more rapidly socialized.

Self-selected recruits are more likely to support organizational norms.

Fragmentation inhibits unitary socialization.

The more bounded the organization, the more effective in socializing.

Organizationally selected recruits are more likely to support organizational norms.

Explicit sanctions/rewards induce utility maximization, not socialization.

Large or diffuse issues facilitate socialization.

Transparent, sizeable material stakes facilitate utility maximization.

Unstable norms discourage preference structuring: socialization and utility maximization are weakened.
Weak support
Strong support
Moderate support
Weak support
Strong support
Weak support
Strong support
Strong support
Strong support
Strong support

ments. ${ }^{71}$ The Commission responded by overhauling its personnel policy. The new policy rejects national quotas, favors merit and seniority, privileges internal promotion over lateral appointments, lays down a code of impartial conduct, and imposes mobility on the higher echelons. The upshot is that, as long as the Commission's organizational mission is in flux, the Commission is in a weak position to shape-either through socialization or through career incentives-top officials' views on Commission norms.

Table 5 summarizes, then, how this empirical study of socialization in the Commission bears on the theory.

\section{Conclusion}

International socialization is hardly a panacea for those interested in diffusing international norms. The European Commission is surely among the most favorable sites for socialization of international norms. Yet the evidence suggests that Commission and international socialization is considerably weaker than socialization outside the Commission.

Why is international socialization weak? One reason is that international organizations rarely benefit from the primacy effect-the opportunity to influence members in their young adult years. The European Commission is an unusual international organization in that 35 percent of its top employees began to work in the Commission in their twenties. Commission socialization is almost exclusively concentrated in this group. It is extremely difficult-nigh impossible-for an international organization to substantially shift the views of mature recruits. 
A second reason for the weakness of international socialization is that international organizations lack control over their members' life chances. Socialization flourishes in homogeneous, bounded environments; it is suppressed when an organization is fragmented and vulnerable to external influences. The European Commission is unusual in that it has more control over its members than all but a few international organizations. It has formal autonomy in recruiting and promoting its personnel. It has the authority to impose mobility on its officials to discourage divergent bureaucratic subcultures. It has extensive supranational powers and the constitutional writ to insulate its work from national and other influences. This is fertile ground for instilling Commission norms. However, the European Commission coexists with national institutions. The Commission sets the agenda, but it must engage the Council of Ministers, individual governments, and the European Parliament in order to legislate. Openness comes at a price: it diminishes the Commission's control over its officials, and induces these people to tap additional loyalties. Hence, even in an international organization as powerful as the Commission, one finds that national norms, originating in prior experiences in national ministries, loyalty to national political parties, or diffuse national political socialization, decisively shape top officials' views on European norms.

One might turn the question around: Why is support for international norms so strong? One conclusion of this study is that there is no intrinsic contradiction between national and international norms. The most powerful influences on proEuropean support among top officials are national or subnational. National and subnational socialization can, and do, produce support for international norms.

Supranationalism can also be generated by utilitarian incentives. One knows that material incentives can nudge state actors toward, or away from, international norms, ${ }^{72}$ and I discern a similar logic at the micro level in the Commission itself. But the causal power of material utility is limited. Views about general principles of international governance are influenced more by ideological predispositions and conceptions of identity than by cost-benefit calculations. This is explicable within the paradigm of rational choice itself: When general governance norms are at issue, the immediate material impact on individual lives tends to be obscure or, to the extent it can be calculated, small.

Finally, there is some circumstantial evidence that self-selection nudges up support for Commission norms. Indeed, individuals who choose to work in an international organization are likely to be favorably disposed to the organization's norms.

There are, then, multiple paths through which preferences may be molded to reflect international norms. International socialization, in the sense of inducting international norms within the organization itself, is one of them. But in the crucial case of the European Commission, international socialization is by no means the most powerful. 


\title{
Appendix 1
}

TABLE A1. Explaining supranationalism

\section{Dependent variable}

SUPRANATIONALISM

Index of two equally weighted items ranging from 1 (strongly opposed) to 7 (strongly in favor): (1) member states should be the central pillars of the EU (item reversed); and (2) Commission should be the government of the European Union.

Independent variables

Socialization variables

\begin{abstract}
LENGTH OF COMMISSION
Years in Commission service. Source: Biographical data from The SERVICE (COMMISSION European Companion 1992, 1994; Euro's Who's Who 1991; SOCIALIZATION) Commission press communications; and interviews by the author.

PRIMACY EFFECT

An interaction term of years in Commission service and (age 65 - age at time of entry).

INTERNATIONAL EDUCATION 4-category variable whereby no international education $=0$, studied in other European country $=1$, studied outside Europe $=2$, and studied in other European country and outside Europe $=3$. Source: Biographical data and interviews.

FEDERALISM

Extent of regional governance combining measures for constitutional federalism, autonomy for special territories in the national state, the role of regions in central government, and presence or absence of direct regional elections. Values range from 0 to 12 , and reflect situation in 1990. Values allocated to top officials according to home country. Source: Hooghe and Marks 2001, app. 2.

SIZE OF COUNTRY Population size of home country of each senior Commission official. Values in millions.

IDEOLOGY For 1996: self-reported partisan affiliation, recoded into ideological 11-point left/right scale. For 2002: self-reported 11-point left/right ideological positioning. Source: Hix and Lord 1997.

NATIONAL ADMINISTRATION Years in national service. Only national state, not posting in Brussels. Source: Biographical data and interview data.
\end{abstract}

\section{Utility maximization variables}

POWER-DG UTILITY

NATIONAL

ECONOMIC BENEFIT
Composite index ranging from 0 to 9 of three measures: (1) DG discretion in regulation, measured as proportion of Commission regulatory output without Council approval; (2) DG discretion in adjudication, measured as the absolute number of Court cases initiated by a DG; and (3) DG reputation from interviews with top officials reporting three or four most powerful Commission DGs. Source: Hooghe 2002.

EU structural aid for 1994-99 as percentage of GDP for each member state. Source: European Commission 1996. Percentage of GDP per country. Extrapolated to 2002. Scores to officials by nationality. 
TABLE A2. Descriptive statistics

\begin{tabular}{lrrrrrr}
\hline Name & $N$ & Mean & Median & Min. & Max. & \multicolumn{1}{c}{$S D$} \\
\hline SUPRANATIONALISM & 198 & 4.61 & 4.75 & 1 & 7 & 1.49 \\
LENGTH OF SERVICE & 198 & 18.71 & 20.00 & 1 & 41 & 10.38 \\
PRIMACY EFFECT & 196 & 618.51 & 608.00 & 7 & 1722 & 438.15 \\
INTERNATIONAL EDUCATION & 196 & 0.73 & 0.00 & 0 & 3 & 0.97 \\
FEDERALISM & 198 & 4.30 & 4.00 & 0 & 10 & 3.08 \\
SIZE OF COUNTRY & 198 & 40.44 & 57.00 & 0.40 & 79.30 & 25.92 \\
IDEOLOGY & 152 & 5.24 & 5.00 & 1.50 & 9.30 & 1.50 \\
YEARS IN NATIONAL ADMINISTRATION & 198 & 5.48 & 1.00 & 0 & 29 & 7.23 \\
POWER-DG UTILITY & 198 & 4.64 & 4.00 & 1 & 9 & 1.94 \\
NATIONAL ECONOMIC BENEFIT & 198 & 0.68 & 0.25 & 0.11 & 3.98 & 1.04 \\
& & & & & &
\end{tabular}

TABLE A3. Correlation matrix

\begin{tabular}{|c|c|c|c|c|c|c|c|c|c|}
\hline & (1) & (2) & (3) & (4) & (5) & (6) & (7) & $(8)$ & (9) \\
\hline $\begin{array}{l}\text { (1) SUPRANATIONALISM } \\
\text { (2) LENGTH OF }\end{array}$ & 1.00 & & & & & & & & \\
\hline SERVICE & $0.16^{*}$ & 1.00 & & & & & & & \\
\hline (3) PRIMACY EFFECT & $0.13^{*}$ & $0.97 * *$ & 1.00 & & & & & & \\
\hline (4) INTERNATIONAL & & & & & & & & & \\
\hline EDUCATION & $0.22 * *$ & 0.01 & -0.00 & 1.00 & & & & & \\
\hline (5) FEDERALISM & $0.33 * *$ & $0.22 * *$ & $0.20 * *$ & $=0.16^{*}$ & 1.00 & & & & \\
\hline (6) SIZE OF COUNTRY & 0.01 & $0.40 * *$ & $0.41 * *$ & -0.04 & $0.44 * *$ & * 1.00 & & & \\
\hline (7) IDEOLOGY & $-0.17^{*}$ & -0.03 & -0.07 & -0.05 & $-0.16^{*}$ & -0.14 & 1.00 & & \\
\hline (8) YEARS IN NATIONAL & & & & & & & & & \\
\hline ADMINISTRATION & $-0.22 * *$ & $-0.50 * *$ & $-0.57 * *$ & $-0.18 *$ & -0.11 & $-0.26 * *$ & 0.11 & 1.00 & \\
\hline (9) POWER-DG UTILITY & 0.04 & -0.00 & -0.00 & -0.05 & 0.06 & 0.00 & 0.02 & 0.02 & 1.00 \\
\hline $\begin{array}{l}\text { (10) NATIONAL } \\
\text { ECONOMIC BENEFIT }\end{array}$ & 0.08 & $-0.26 * *$ & $-0.23 * *$ & $0.17 *$ & $-0.28 * *$ & $*-0.39 * *$ & 0.01 & 0.04 & $-0.14 *$ \\
\hline
\end{tabular}

Note: $* * p<.01 ; * p<.05$. 


\section{Appendix 2}

TABLE A4. The effect of socialization in selective DGs (Power DG)

$\begin{array}{lr}\text { Constant } & 3.849(1.369)^{* * *} \\ \text { International socialization } & \\ \text { LENGTH OF SERVICE IN COMMISSION } & 0.033(.027) \\ \text { INTERNATIONAL EDUCATION } & 0.215(.259) \\ \text { POWER-DG SOCIALIZATION } & -0.003(.036) \\ \text { Socialization outside Commission } & \\ \text { STATE STRUCTURE (POOLED/UNITARY SOVEREIGNTY): } & 0.188(.80)^{*} \\ \quad \text { FEDERALISM } & -0.020(.010)^{\circ} \\ \quad \text { SIZE } & -0.132(.151) \\ \text { IDEOLOGY } & -0.030(.036) \\ \text { YEARS IN NATIONAL ADMINISTRATION } & \\ \text { Utility factors } & 0.132(.116) \\ \text { POWER-DG UTILITY } & -0.030(.036) \\ \text { NATIONAL ECONOMIC BENEFIT } & 0.268 \\ R^{2} & 0.139 \\ \text { Adjusted } R^{2} & 105 \\ N & \end{array}$

Note: Ordinary least squares (OLS) regression for 1996 sample. Coefficients are unstandardized. Standard errors are in parentheses. OLS regression analysis with pairwise deletion. $* * p<.01 ; * p<.05 ;{ }^{\circ} p<.15$.

TABLE A5. The effect of selective recruitment by Commission presidents

$\begin{array}{lr}\text { Constant } & 4.141(.748)^{* *} \\ \text { International socialization } & 0.017(.014) \\ \text { LENGTH OF SERVICE IN COMMISSION } & 0.156(.122) \\ \text { INTERNATIONAL EDUCATION } & \\ \text { Socialization outside Commission } & 0.181(.043)^{* *} \\ \text { STATE STRUCTURE (POOLED/UNITARY SOVEREIGNTY): } & -0.012(.006)^{*} \\ \quad \text { FEDERALISM } \quad-112(.078)^{\circ} \\ \quad \text { SIZE } & -0.028(.019)^{\circ} \\ \text { IDEOLOGY } & \\ \text { YEARS IN NATIONAL ADMINISTRATION } & 0.033(.059) \\ \text { Utility factors } & 0.184(.123)^{\circ} \\ \text { POWER-DG UTILITY } & \\ \text { NATIONAL ECONOMIC BENEFIT } & \\ \text { Selective recruitment } & 0.287(.345) \\ \text { DELORS RECRUIT } & 0.168(.371) \\ \text { SANTER RECRUIT } & 0.322(.463) \\ \text { PRODI RECRUIT } & 0.230 \\ R^{2} & 0.169 \\ \text { Adjusted } R^{2} & 198 \\ N & \end{array}$

Note: Ordinary least squares (OLS) regression for pooled sample. Coefficients are unstandardized. Standard errors are in parentheses. OLS regression analysis with pairwise deletion. $* * p<.01 ; * p<.05 ;{ }^{\circ} p<.15$. 


\section{Appendix 3}

TABLE A6. Views on supranationalism

\section{Dependent variable}

SUPRANATIONALISM

Index of two equally weighted items ranging from 1 (strongly opposed) to 7 (strongly in favor): (1) member states should be the central pillars of the EU (item reversed); and (2) Commission should be the government of the European Union.

Independent variables

Socialization variables: See Table A1.

Utility maximization variables: See Table A1 and the following.

NATIONAL CLUBNESS $H$ : The better one's nationality is organized in Brussels, the more an official has career incentives to support intergovernmentalism and oppose supranationalism. $O$ : Index measuring degree of cohesion, organizational resources, national government's policy toward compatriots, and Commission cabinet resources of nationalities in Brussels; the degree of organization determines the effectiveness of nationalities in pushing career interests of their compatriots. Values are $1=$ weak, 2 = medium, $3=$ strong. Source: Hooghe 2002. Values allocated to officials by nationality.

PARACHUTAGE $\quad H$ : A parachuted official is likely to support intergovernmentalism to pay back the government that helped appoint him. $O$ : Dummy for official who was externally appointed into a senior position.

Note: $H=$ Hypothesis; $O=$ Operationalization.

TABLE A7. Views on Commission agenda setting

\section{Dependent variable} favor). 
TABLE A7. (CONTINUED)

Independent variables

Socialization variables

COMMISSION SOCIALIZATION $\quad H$ : The longer an official has served in the Commission, the more likely he internalizes support for Commission agenda setting. O: See Table A1.

INTERNATIONAL EDUCATION $H$ : An internationally educated official is more likely to be socialized into wanting maximal Commission agenda setting. $O$ : See Table A1.

IDEOLOGY

$H$ : A left-oriented official is more likely to prefer Commission agenda setting because it increases political regulation of the single market. $O$ : See Table A1.

PRIVATE-SECTOR EXPERIENCE $H$ : An official with private-sector managerial experience is more likely to prefer a managerial Commission. $O$ : Dummy with value of 1 if official had experience in industry or banking.

Source: Biographical data and interviews.

NATIONAL ADMINISTRATIVE $H$ : An official socialized in Weberian administrative tradition is TRADITION more likely to prefer an agenda-setting Commission than an official from a weak Weberian administration. $O$ : Dummies for weak-Weberian, medium-Weberian, strong-Weberian. Values allocated by nationality to officials with national administrative experience. Source: Page 1995; and Page and Wright 1999.

Utility maximization variables

NATIONAL ECONOMIC BENEFIT

DELORS RECRUIT

AGE

ADMINISTRATIVE/ MANAGERIAL-DG UTILITY

SOFT-DG UTILITY
$H$ : An official from a country that draws net benefits from the EU has material incentives to prefer Commission agenda setting because an active Commission is likely to deepen positive integration. $O$ : See Table A1.

$H$ : An official appointed under Delors to run the internal market program has career incentives to emphasize Commission management. $O$ : Dummy with value of 1 if official was recruited to top position under Commission president Jacques Delors. Source: Biographical data.

$H$ : A younger official has career incentives to emphasize Commission agenda setting. $O$ : Age of official at time of interview.

$H$ : An official from an administrative-managerial DG has career incentives to oppose Commission agenda setting. O: Dummy taking a value of 1 for officials in DGs with tasks that are primarily routine administration, implementation or adjudication; consistent with the definition of managerial roles by Page 1997.

$H$ : Officials from DGs with soft nonbudgetary power have career incentives to prefer Commission agenda setting. $O$ : Dummy taking a value of 1 for officials working in a DG concerned with policy areas that use most frequently benchmarking, soft law, peer group pressure, technical reporting, and other soft policy instruments. Source: Interview data. 
TABLE A8. Views on Commission autonomy from national influence

\section{Dependent variable}

COMMISSION AUTONOMY
Index of two equally weighted items tapping into views on national quota, and on national dossiers. The index ranges from 1 (strongly opposed) to 7 (strongly in favor). Wording differs between 1996 and 2002.

Items in 1996: (1) "It hurts Commission legitimacy that certain DGs tend to be dominated by particular nationalities," and (2) "Too many Commission officials let their nationality interfere with professional judgments."

Items in 2002: (1) "Some argue that positions in the Commission should be distributed across nationalities proportionate to respective populations (item reversed)," and (2) "Some think that it is preferable to have dossiers of special interest to particular nationalities managed by officials of those nationalities (item reversed)."

Independent variables

\section{Socialization variables}

COMMISSION SOCIALIZATION $H$ : The longer an official has served the Commission, the more he is likely to have internalized the norm of Commission autonomy. $O$ : See Table A1.

INTERNATIONAL EDUCATION $H$ : An internationally educated official is more likely to be socialized into wanting autonomy from national influence.

$O$ : See Table A1.

CABINET EXPERIENCE

$H$ : An official with cabinet experience is likely to appreciate the need to work closely with nationals. $O$ : A dummy with the value of 1 if an official has served in a Commission cabinet.

NATIONAL ADMINISTRATIVE $H$ : An official who worked previously in a Weberian administration TRADITION prefers a Commission autonomous from national interest. $O$ : See Table A7.

\section{Utility maximization variables}

PARACHUTAGE

SOFT-DG UTILITY

NATIONAL CLUBNESS

NATIONAL QUOTA
$H$ : A parachuted official has career incentives to oppose Commission autonomy from national influence. $O$ : See Table A6.

$H$ : An official from a soft DG has career incentives to cooperate with national stakeholders, which leads to opposition of the Commission norm. $O$ : See Table A7.

$H$ : The better one's nationality is organized in Brussels, the more an official has career incentives to oppose Commission autonomy from national influence. $O$ : See Table A6.

$H$ : An official from a country with a small quota has career incentives to support Commission autonomy from national influence. $O$ : Number of votes in the Council of Ministers, which is used in the Commission as a proxy for determining national quota of Commission jobs. Variable ranges between 2 and 10. Scores allocated to officials by nationality. 


\section{References}

Abélès, Marc, and Irène Bellier. 1996. La Commission européenne: du compromis culturel à la culture politique du compromis. Revue Française de Science Politique 46 (3):431-56.

Allison, Graham T. 1971. Essence of Decision: Explaining the Cuban Missile Crisis. Boston: Little, Brown.

Beck, Paul, and M. Kent Jennings. 1991. Family Traditions, Political Periods, and the Development of Partisan Orientation. Journal of Politics 53 (3):742-63.

Caporaso, James. 2000. Changes in the Westphalian Order: Territory, Public Authority, and Sovereignty. International Studies Review 2 (2):1-28.

Checkel, Jeffrey. 2003. 'Going Native' in Europe? Theorizing Social Interaction in European Institutions. Comparative Political Studies 36 (1):209-31.

Chong, Dennis. 2000. Rational Lives: Norms and Values in Politics and Society. Chicago: University of Chicago Press.

Citrin, Jack, Donald P. Green, Christopher Muste, and Cara Wong. 1997. Public Opinion Toward Immigration Reform: The Role of Economic Motivations. Journal of Politics 59 (3):858-81.

Conover, Pamela Johnston. 1991. Political Socialization: Where's the Politics? In Political Science: Looking to the Future, Vol. 3, edited by William Crotty, 125-52. Evanston, Ill.: Northwestern University Press.

Coombes, David. 1970. Politics and Bureaucracy of the European Community: A Portrait of the Commission of the E.E.C. London: Allen and Unwin.

Cram, Laura. 1994. The European Commission as a Multi-Organization: Social Policy and IT Policy in the EU. Journal of European Public Policy 1 (2):195-217.

Crano, William D. 1997. Vested Interest, Symbolic Politics, and Attitude-Behavior Consistency. Journal of Personality and Social Psychology 72 (3):485-91.

Dod's European Companion. 1992, 1994. London: Dod's Politial Publishing.

Druckman, Daniel. 1994. Nationalism, Patriotism, and Group Loyalty: A Social Psychological Perspective. Mershon International Studies Review 38 (1):43-68.

Duchêne, François. 1994. Jean Monnet: The First Statesman of Interdependence. New York: Norton.

Eckstein, Harry. 1975. Case Study and Theory in Political Science. In Handbook of Political Science, Vol. 7, edited by Fred I. Greenstein and Nelson W. Polsby, 79-137. Reading, Mass.: Addison-Wesley.

Egeberg, Morten. 1999. Transcending Intergovernmentalism? Identity and Role Perceptions of National Officials in EU Decision-Making. Journal of European Public Policy 6 (3):456-74.

Elster, Jon. 1990. When Rationality Fails. In The Limits of Rationality, edited by Karen Schweers Cook and Margaret Levi, 19-51. Chicago: University of Chicago Press.

Evans, Geoffrey. 2002. European Integration, Party Politics and Voting in the 2001 Election. British Elections and Parties Review 12:95-110.

European Commission. 1996. First Report on Economic and Social Cohesion 1996. DG XVI, 144, Table 24. Brussels: European Commission.

European Convention. 2003. Draft Treaty Establishing a Constitution for Europe. CONV 850/03. Brussels: European Parliament.

Euro's Who's Who: Who's Who in the European Communities and in the Other European Organizations. 1991. Brussels: Editions Delta.

Fearon, James, and Alexander Wendt. 2003. Rationalism versus Constructivism: A Skeptical View. In Handbook of International Relations, edited by Walter Carlsnaes, Thomas Risse, and Beth A. Simmons, 52-72. London: Sage.

Finnemore, Martha. 1996. National Interests in International Society. Ithaca, N.Y.: Cornell University Press.

Gabel, Matthew, and Chris Anderson. 2002. The Structure of Citizen Attitudes and the European Political Space. Comparative Political Studies 35 (8):893-913.

Goren, Paul. 2001. Core Principles and Policy Reasoning in Mass Publics: A Test of Two Theories. British Journal of Political Science 31 (1):159-77. 
Haas, Ernst. 1958. The Uniting of Europe: Political, Social and Economic Forces, 1950-1957. Stanford, Calif.: Stanford University Press.

Hartung, Harald. 2001. Eurobarometer 54.1: Building Europe and the European Union: The European Parliament, Public Safety, and Defense Policy, November-December 2000. Brussels: European Opinion Research Group EEIG.

Hemmer, Christopher, and Peter Katzenstein. 2002. Why Is There No NATO in Asia? Collective Identity, Regionalism, and the Origins of Multilateralism. International Organization 56 (3):575-607.

Hix, Simon, and Christopher Lord. 1997. Political Parties in the European Union. London: MacMillan.

Hooghe, Liesbet, and Gary Marks. 2001. Multi-Level Governance and European Integration. Lanham, Md.: Rowman \& Littlefield.

- 2002. The European Commission and the Integration of Europe: Images of Governance. Cambridge: Cambridge University Press.

- 2003. Europe Divided? Elites vs. Public Opinion on European Integration. European Union Politics 4 (3):281-305.

- 2003. Unraveling the Central State, but How? Types of Multi-Level Governance. American Political Science Review 97 (2):233-43.

Huddy, Leonie. 2003. Group Identity and Political Cohesion. In Oxford Handbook of Political Psychology, edited by David O. Sears, Leonie Huddy, and Robert Jervis, 511-58. Oxford: Oxford University Press.

Hug, Simon, and Thomas König. 2002. In View of Ratification: Governmental Preferences and Domestic Constraints at the Amsterdam Intergovernmental Conference. International Organization 56 (4):447-76.

Jennings, M. Kent. 1992. Ideological Thinking among Mass Publics and Political Elites. Public Opinion Quarterly 56 (4):419-41.

Jennings, M. Kent, and Laura Stoker. 2001. The Persistence of the Past: The Class of 1965 Turns Fifty. Berkeley: Institute of Governmental Studies, University of California at Berkeley.

Johnston, Alastair Iain. 2001. Treating International Institutions as Social Environments. International Studies Quarterly 45 (4):487-515.

Kelly, Judith. 2004. International Actors on the Domestic Scene: Membership Conditionality and Socialization by International Institutions. International Organization 58 (3):425-57.

Keohane, Robert O. 2002. Ironies of Sovereignty: The European Union and the United States. Journal of Common Market Studies 40 (4):743-65.

Legro, Jeffrey. 1996. Culture and Preferences in the International Cooperation Two-Step. American Political Science Review 90 (1):118-37.

Lindberg, Leon N., and Stuart A. Scheingold. 1970. Europe's Would-Be Polity: Patterns of Change in the European Community. Englewood Cliffs, N.J.: Prentice-Hall.

Linden, Ronald H., ed. 2002. Norms and Nannies: The Impact of International Organizations on the Central and East European States. Lanham, Md.: Rowman \& Littlefield.

March, James G., and Johan P. Olsen. 1989. Rediscovering Institutions: The Organizational Basis of Politics. New York: Free Press.

Marks, Gary, and Marco Steenbergen, eds. 2004. European Integration and Political Conflict. Cambridge: Cambridge University Press.

Marks, Gary, Liesbet Hooghe, Moira Nelson, and Erica Edwards. 2006. Party Competition and European Integration in East and West: Different Structure, Same Causality. Comparative Political Studies 39.

McKeown, Timothy. 2004. Case Studies and the Limits of the Quantitative Worldview. In Rethinking Social Inquiry: Diverse Tools, Shared Standards, edited by Henry E. Brady and David Collier, 13967. Lanham, Md.: Rowman \& Littlefield.

Nordlinger, Eric. 1981. On the Autonomy of the Democratic State. Cambridge: Cambridge University Press.

Page, Edward. 1995. Administering Europe. In Governing the New Europe, edited by Jack Hayward and Edward Page, 257-85. Durham, N.C.: Duke University Press. 
1997. People Who Run Europe. Oxford: Clarendon/Oxford University Press.

Page, Edward C., and Vincent Wright, eds. 1999. Bureaucratic Elites in Western European States: A Comparative Analysis of Top Officials. Oxford: Oxford University Press.

Peterson, John. 1999. The Santer Era: The European Commission in Normative, Historical and Theoretical Perspective. Journal of European Public Policy 6 (1):46-55.

Pollack, Mark. 2000. The End of Creeping Competence? EU Policy-Making Since Maastricht. Journal of Common Market Studies 38 (3):519-38.

. 2003. The Engines of European Integration: Delegation, Agency, and Agenda Setting in the $E U$. Oxford: Oxford University Press.

Putnam, Robert. 1973. The Beliefs of Politicians: Ideology, Conflict and Democracy in Britain and Italy. New Haven, Conn.: Yale University Press.

Risse, Thomas. 2000. 'Let's Argue!': Communicative Action in World Politics. International Organization 54 (1):1-39.

2001. A European Identity? Europeanization and the Evolution of Nation-State Identities. In Transforming Europe: Europeanization and Domestic Change, edited by Maria Green Cowles, James Caporaso, and Thomas Risse, 198-216. Ithaca, N.Y.: Cornell University Press.

Risse, Thomas, Stephen Ropp, and Kathryn Sikkink, eds. 1999. The Power of Human Rights: International Norms and Domestic Change. Cambridge: Cambridge University Press.

Ross, George. 1995. Jacques Delors and European Integration. New York: Oxford University Press.

Searing, Donald. 1986. A Theory of Political Socialization: Institutional Support and Deradicalization in Britain. British Journal of Political Science 16 (3):341-76.

1991. Roles, Rules and Rationality in the New Institutionalism. American Political Science Review 32 (1):47-68.

- 1994. Westminster's World: Understanding Political Roles. Cambridge: Cambridge University Press.

Searing, Donald, Gerald Wright, and George Rabinowitz. 1976. The Primacy Principle: Attitude Change and Political Socialization. British Journal of Political Science 6 (1):83-113.

Sears, David O. 1993. Symbolic Politics: A Socio-Psychological Theory. In Explorations in Political Psychology, edited by Shanto Iyengar and William J. McGuire, 113-49. Durham, N.C.: Duke University Press.

Sears, David O., and Carolyn Funk. 1991. The Role of Self-Interest in Social and Political Attitudes. Advances in Experimental Social Psychology 24 (1):1-91.

- 1999. Evidence of the Long-Term Persistence of Adults' Political Predispositions. Journal of Politics 61 (1):1-28.

Sears, David O., and Sheri Levy. 2003. Childhood and Adult Political Development. In Oxford Handbook of Political Psychology, edited by David O. Sears, Leonie Huddy, and Robert Jervis, 60-109. Oxford: Oxford University Press.

Sears, David O., and Nicholas A. Valentino. 1997. Politics Matters: Political Events as Catalysts for Preadult Socialization. American Political Science Review 91 (1):45-65.

Shore, Cris. 2000. Building Europe: The Cultural Politics of European Integration. London: Routledge.

Simon, Herbert A. 1985. Human Nature in Politics: The Dialogue of Psychology with Political Science. American Political Science Review 79 (2):293-304.

Spence, Jacqueline M. 1996. The European Union 'A View from the Top': Top Decision Makers and the European Union. Prepared for EOS Gallup Europe's European Omnibus Survey. Brussels: EOS Gallup Europe. Available at: 〈http://europa.eu.int/comm/public_opinion/archives/top/top_en.htm〉. Accessed 22 June 2005.

Taber, Charles S. 2003. Information Processing and Public Opinion. In Oxford Handbook of Political Psychology, edited by David O. Sears, Leonie Huddy, and Robert Jervis, 433-76. Oxford: Oxford University Press.

Thomassen, Jacques, Abdul Noury, and Erik Voeten. 2004. Political Competition in the European Parliament: Evidence from Roll Call and Survey Analyses. In European Integration and Political Conflict, edited by Gary Marks and Marco Steenbergen, 141-64. Cambridge: Cambridge University Press. 
Van der Eijk, Cees, and Mark N. Franklin. 2004. Potential for Contestation on European Matters at National Elections in Europe. In European Integration and Political Conflict, edited by Gary Marks and Marco Steenbergen, 32-50. Cambridge: Cambridge University Press.

Wessels, Bernhard. 2004. Contestation Potential of Interest Groups in the EU: Emergence, Structure, and Political Alliances. In European Integration and Political Conflict, edited by Gary Marks and Marco Steenbergen, 195-215. Cambridge: Cambridge University Press.

Young, Jason, Cynthia J. Thomsen, Eugene Borgida, John L. Sullivan, and John H. Aldrich. 1991. When Self-Interest Makes a Difference: The Role of Construct Accessibility in Political Reasoning. Journal of Experimental Social Psychology 27:271-96.

Zaller, John. 1992. The Nature and Origins of Mass Opinion. Cambridge: Cambridge University Press. 